\title{
FRESCOES IN THE GOSPA OD LUŽINA CHURCH IN STON
}

\author{
Tatjana Mićević - Đurić
}

\author{
T. Mićević - Đurić \\ Sveučilište u Mostaru \\ Filozofski fakultet \\ Matice hrvatske bb, 88000 Mostar, \\ Bosna i Hercegovina \\ infozone1@zg.t-com.hr
}

\begin{abstract}
This paper presents the frescoes in the church Gospa od Lužina, previously hidden under layers of plaster. The only preserved frescoes are in the eastern part of the church, in the apse and on the triumphal arch, depicting fathers of the church, the Agnus Dei (?), and St. Blase and Lazarus, and those on both lateral walls next to the apse, where a few Franciscan and Dominican monks are depicted and the only narrative scene, The Nativity.

Both, the iconography and the style of these frescoes indicate the art distanced from medieval artistic forms which confirm relationship to the contemporary artistic movements in Italy. Because of its stylistic features as well as some iconographic indication this painting is dated in the last two decades of the $15^{\text {th }}$ century. Attribution cannot be proposed with any certainty.
\end{abstract}

Key words: Gospa od Lužina church, frescoes, doctors of the church, Agnus Dei, St. Francis, St. Dominic, St. Vincent Ferrer, St. Anthony of Padua, Nativity, Quattrocento

The church dedicated to the Assumption of Mary, called the Gospa od Lužina Church, is situated in the field toward the famous Ston saltern.

In art history this church has been known for a very long time. ${ }^{1}$ But the last researches carried out during the nineties of the $20^{\text {th }}$ century set forward the time of its construction to the advanced $13^{\text {th }}$ century. They have revealed some new facts about later additional interventions on the church, ${ }^{2}$ and discovered remains of the wall paintings that were completely unknown. ${ }^{3}$ These frescoes will be presented here. ${ }^{4}$

The largest painted area is preserved in the apse. It is situated in the central register of the apsidal wall where six standing figures in full height are depicted under the painted arcade. Three of them are on the left and three others are on the right side of the rectangular window in the centre of the apse.

Three saints on the northern side of the apse are dressed the same, similar to the Hellenistic robe with himation. The first one is in his middle age, very corpulent, characterized by a round face, dark brown hair and beard of medium length. The age and physiognomy of the saint next to him cannot be recognized because of the damage. The third saint, better preserved than others, is a younger one

\footnotetext{
${ }^{1}$ At the end of the $19^{\text {th }}$ century it was described as an example of the Preromanesque. See: F. RADIĆ, Sredovječne crkve u Stonu, in Starohrvatska prosvjeta (1898.) IV. 3 and 4, p. 72-81, 140-145.

${ }^{2}$ The researches, begun in 1990, were stopped during the war and started again in 1995. See: K. REGAN, B. NADILO, Ranokršćanske i predromaničke crkve u Stonu, Crkveno graditeljstvo, in Građevinar 58 (2006) 9, p. 761-762; N. NAĐ, Crkva Gospe od Lužina u Stonskom polju in Dubrovnik (2000.) XI.,1-2, p. 249-254.

${ }^{3}$ I thank prof. I. Fisković who drew my attention to the wall paintings in this church.

${ }^{4}$ Since these frescoes were never previously described, I am going to give their full description. This wall painting is mentioned in the review of the church by N. Nad. Also, Vinicije. B. Lupis mentioned it in his book on sacral art in Ston. See: N. NAĐ, op. cit., p. 250; V. B. LUPIS, Sakralna baština Stona i okolice, Ston, 2000., p. 113.-114.
} 


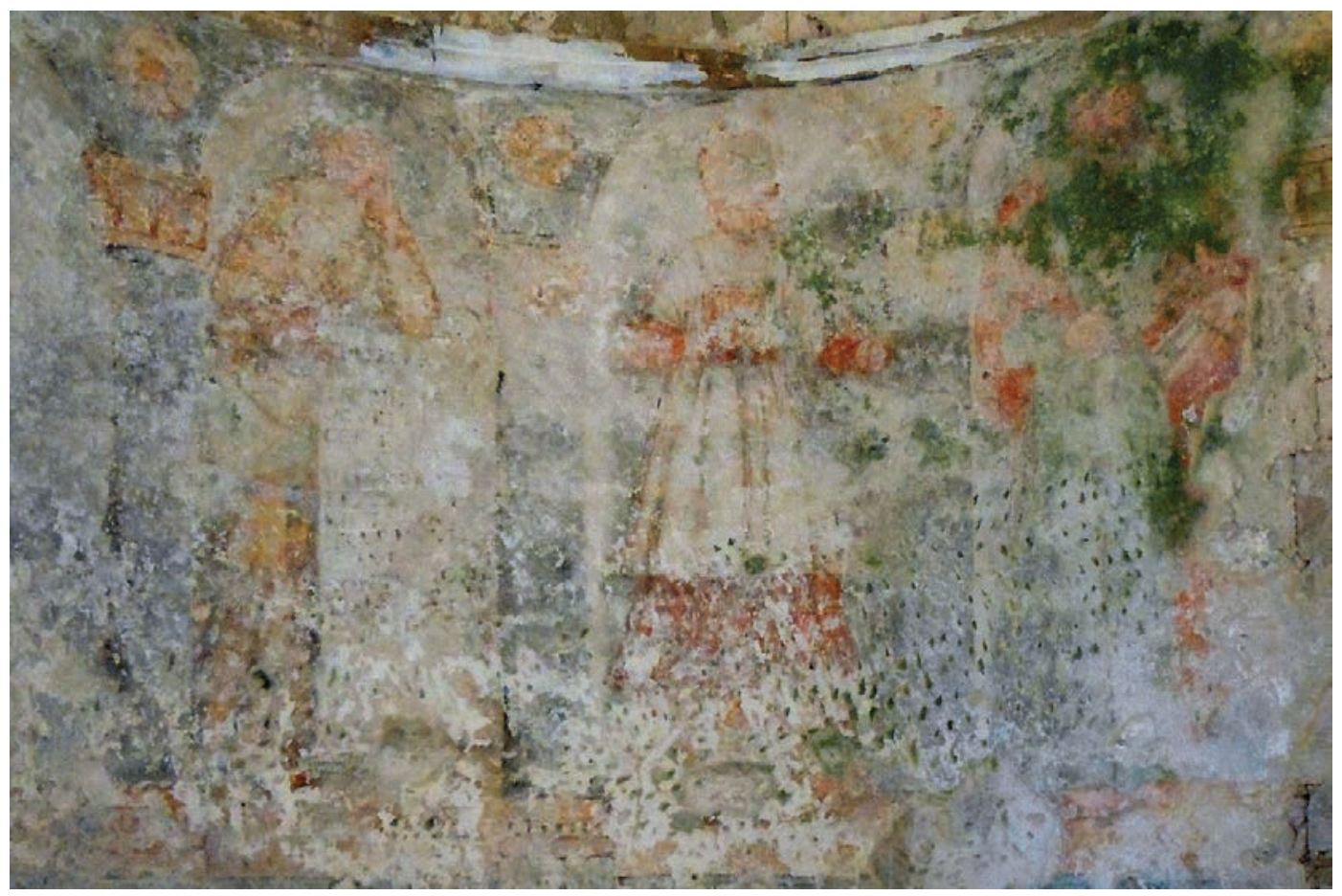

Fig. 1. Latin Doctors, the southern side of the apse, Gospa od Lužina Church in Ston

with a shorter beard and almost closed eyes. He is not depicted frontally, like the two others. His head is inclined to the left. In his left hand he holds a large white unfolded roll with an inscription in Latin and the right one is on his chest. Three saints depicted on the south side of the apse have similar poses and similar features. (fig. 1) The only difference is the clothes of the saint in the middle who is dressed in the liturgical clothes of the Roman church priest. His Episcopalian rank is shown by the high mitre and the bishop's staff. Their physiognomies cannot be seen except the saint nearest to the nave with a beardless face that indicates a younger age and large, brown eyes nicely framed by dark, arched eyebrows which look at us. These six monumental figures form a nicely unified symmetrical composition.

Despite the very bad condition of the frescoes there is no doubt that the figures depicted below the arcade on the apsidal wall represent the fathers of the church. This conclusion is supported by a few elements. The first, figural frieze on the apsidal wall is a common iconographic program used in Christian churches from the very early time..$^{5}$ During the time that place was given to the church fathers or the doctors of the church, ${ }^{6}$ the saints to whom we owe the definition of church doctrine. ${ }^{7}$ Furthermore, almost all of them, as much as can be seen, hold in their arms books or scrolls that are common attribute of doctors. Also, their clothes, except one of them, ${ }^{8}$ belong to the Hellenistic tradition that indicates their ancient origins.

Still, the question of their identities remains unsolved. It is impossible to assume which person is represented by which figure, even which persons are represented in this frieze. The catholic character

\footnotetext{
${ }^{5}$ In that place various categories of saints were depicted - apostles, martyrs, bishops localy venerated... See: V. N. LAZAREV, Istorija vizantijskog slikarstva, Beograd, 2004., p. 21.-52.

${ }^{6}$ At first they were depicted frontaly and later in Byzantine art, after the introduction of the symbolic image of Christ in the centre, they became the composition of the Holy Liturgy or Adoration of the Archibishops. Such depictions and their meanings were absolutely adequate for the apse. See: Z. M. JOVANOVIĆ, Azbučnik pravoslavne ikonografije i graditeljstva, Beograd, 2005., p. 267.-275., 400.-403.

${ }^{7}$ R. E. GUILEY, The Encyclopedia of Saints, New York, 2001., p. 378.

${ }^{8}$ The saint in the middle of the southern part of the apse is dressed in clothes of a highly ranked church official.
} 


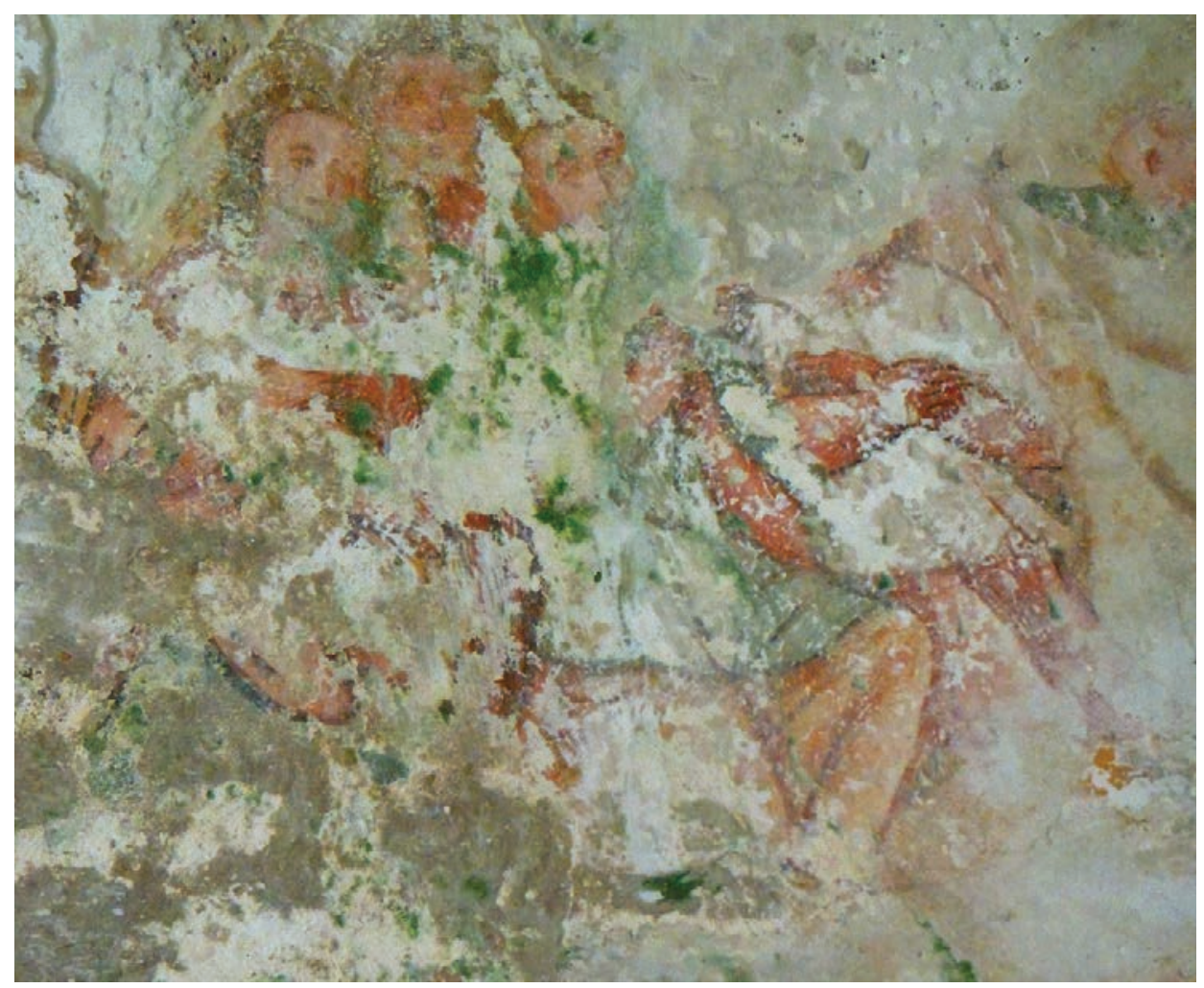

Fig. 2. The remains of frescoe in the semidome of the apse, Gospa od Lužina Church in Ston

of this church is unquestionable, so the most logical assumption is that they are all four Latin doctors of the church, SS. Augustine, Ambrose, Jerome and Gregory the Great. Hardly legible inscription on the scroll which is held by the saint shown on the right of the window indicates the possibility that this figure represents St. Ambrose. The words like "eyes" (OCVLI) or "tears" ('ACRIM·) indicate some poem, not a prayer. ${ }^{9}$

The number of depicted persons - six - is quite interesting. Who are the other two persons set into the same rank as the Latin doctors? Could they be two of the Eastern fathers? ${ }^{10}$ Or could they be two of western saints who gained the rank of the church doctors due to their contribution to the development of the theological ideas in the Catholic Church 11 $^{11}$ The later assumption is more acceptable. ${ }^{12}$

The only part of the other paintings in the apse is a small fragment preserved in the lower northern part of the apsidal semi-dome on which a few young looking persons who are lying or sitting can be recognized (fig. 2). Three young heads, beardless and of nice features, lovely expression and beautiful haircuts are placed one beside the other. They are quite damaged, so their number, posture and appearance are uncertain. Due to the postures of these heads and bodies as well as the gazes directed toward the centre of the space, it seems that they made a part of a large composition depicted on the whole surface of the apsidal semi-dome. One child's head turned toward the centre of the semi-dome while it is flying toward the youths, a cherub perhaps, has been its part, too.

\footnotetext{
${ }^{9}$ These readings are made by Pavao Knezović.

${ }^{10}$ There are examples where Eastern and Latin doctors appear together in monumetntal painting as it is in the $14^{\text {th }}$ century mosaic in St Mark's in Venice. See: P. MURRAY, L. MURRAY, The Oxford Companion to Christian Art and Architecture, Oxford - New York, 1996., 139.

${ }^{11}$ R. E. GUILEY, op. cit,378.

${ }^{12}$ For example, they could be St. Thomas Aquinas, the greatest Dominican philosopher and theologian and St. Bonaventure, the Franciscan theologian, who gained the the title of Doctor of the Church together in 1257. See: http:// www.newadvent.org/cathen/02648c.htm, Downloaded: November 2013.
} 
It is very difficult to presume the content of this composition, so the answer to the question about the climax of the iconographic program in this church has to remain unsolved. ${ }^{13}$ Just a hypothesis can be given. The figures of youth, maybe angels, and cherub could be a part of a large Agnus Dei. ${ }^{14}$ Because of its meaning, an Agnus Dei is absolutely appropriate for an altar space. There are examples of depiction of the Lamb of God in apses or other wall surfaces of altar space since the Early Christian art. ${ }^{15}$ But, there are no examples derived from the older periods or contemporary time that could be directly linked to the iconography supposed for this apse. At the same time it must be noticed that the Agnus Dei has become popular in the late Gothic panel painting, when the depiction of the Lamb was enriched with the angel's choirs who play music and worship the Lamb. ${ }^{16}$

The fragments in the semi-dome could testify another theme such as the Coronation of the Virgin or Christ with the Virgin on thrones that would be appropriate to the church's dedication. But remains of the frescoes above the apse showing the lower parts of a figure in red robe and angels who are flying toward her as well as the inscription "SUMPT." indicate the Virgin, probably the Assumption. This meaning would reduce the other depiction of the Virgin in the apse.

There are two more fragments of frescoes on the eastern wall, in the basis of triumphal arch. On the southern side of the arch St. Blase, giving blessings by his right hand and holding the model of Ston, is depicted. This depiction matches the usual iconography of the saint, the protector of the Republic of Dubrovnik and the town of Ston. So there is no doubt about his identity. But the identity of the other saint, shown on the northern side of this arch, is much more difficult to recognize. Firstly, the depiction is severely damaged, and secondly, it is quite unusual. The fragment shows parts of the clothes of an eastern bishop. ${ }^{17}$ The most indicative part for the identification of this saint is his attribute, a rectangular stone grave frame on whose upper beam one stone is rolling. It is a clear indication of St. Lazarus of Bethany. ${ }^{18}$ Despite the rarity of such depictions of this saint, as an individual saint bishop, there is no doubt of this identification. ${ }^{19}$ It is supported by his role as the patron saint of leprosy, ${ }^{20}$ and the importance of the plague protection in the medieval Dubrovnik. ${ }^{21}$

These two saint bishops and the central figure in the top of the eastern wall, very probably Mary, altogether with the composition in the apsidal semi-dome, Agnus Dei (?) and the church fathers, present the most important part of the painting decoration in this church. It consists of the most important points of the Christian dogma, Mary in Assumption, the one who gave the Saviour to the humankind in glory, and the symbolically presented Christ indicating and emphasising his victim role on behalf of the whole humankind as well as the locally venerated saints. The choice of

\footnotetext{
${ }^{13}$ In the art of plane Middle Ages, this surface was designated for very important depictions like the Virgin Mary, mostly in the East, or Maiestas Domini, in the West. None of these contents was represented in this apse.

${ }^{14}$ P. MURRAY, L. MURRAY, op. cit., p. 6., Leksikon ikonografije, liturgije i simbolike zapadnog kršćanstva, A. BADURINA (ed.), Zagreb 2000., p., 120.-121.; http://www.newadvent.org/cathen/01220a.htm, Downloaded: November 2013. ${ }^{15}$ By the $5^{\text {th }}$ and $6^{\text {th }}$ centuries the Lamb took the place of Jesus. It appears in the vault of the baptistery of St John in Lateran, the presbytery vault of Ravenna's S. Vitale, in the apse of the church of Saints Cosmas and Damian in Rome. It also appears on ivory covers made for gospel books and on numerous sarcophagi See: R. M. JENSEN, Understanding Early Christian Art, London - New York, 2000., p. 107, 157.

${ }^{16}$ R. COGNIAT, Histoire de la peinture (tome I.), Paris, 1954., p. 39.-73.; J. DUPONT, C. GNUDI, La peinture Gothique, (Les grands siècles de la peinture), p. 49.-206. Leksikon ikonografije, op. cit., p. 120.-121.

${ }^{17}$ The saint has got two long strips over the robe - epitrahilj, the insignia of the eastern bishop.

${ }^{18}$ F. LANZI, G. LANZI, Saints and their symbols: recognizing saints in art and in popular images, Collegville, 2004., p.47.

${ }^{19}$ R. E. GUILEY, The Encyclopedia of Saints, New York, 2001., p.206.; http://www.newadvent.org/ cathen/09097a. htm, Downloaded: November 2013.

${ }^{20}$ Strong veneration of St. Lazarus in the Republic of Dubrovnik is confirmed by the name of the quarantine - lazareti as well as the name of the largest saline pools in Ston's saltern.

${ }^{21}$ G. RAVANČIĆ, Crna smrt 1348. - 1349. u Dubrovniku, Srednjovjekovni grad i doživljaj epidemije (doctoral disertation), Zagreb, Filozofski fakultet, 2006.
} 
the contents depicted on the eastern wall of this church reveals general and timeless character of the Christianity linking it with the town of Ston.

But, there are also some new, contemporary iconographic themes, exclusively western, which mark Ston as a place that is well informed about the current situation in the church and church art and included in it.

One of those "new" depictions is the figure situated in the southeastern corner of the nave next to the apse. Despite of the damages, simple brown clothes, bare feet, the physiognomy of a young man, probably beardless with obvious tonsure, attributes - book and a cross clearly indicates St. Frances. This is supported by the depiction on the opposite wall where figure of St. Dominic can be assumed. Unfortunately, just its lower part which reminds to a monk's robe of pale grey colour is preserved. As it is adequate to St. Francis's image on the opposite wall, this is good indication of St. Dominic. So, in the Gospa od Lužina Church, two important and venerated saints, the founders of very influential church orders are placed close to the most sacred church's space - altar apse. This reflects the importance and influence of the Franciscan and Dominican church orders whose preachers were accepted everywhere in the late Middle Ages and understandable to all. ${ }^{22}$

These ideas were an important element of the iconographic program realized in this church. It is obvious in the remains in the blind rectangular niche, next to St. Francis, where SS. Vincent Ferrer and Anthony of Padua are depicted. St. Vincent Ferrer is on the eastern side of the niche, presented as a younger, beardless saint dressed in white robe and dark mantle. (fig. 3) The most important indication in identification of this saint is the clothes of a Dominican monk and the attributes - book and flame. ${ }^{23}$



Fig. 3. St. Vincent Ferrer, the southern wall, Gospa od Lužina Church in Ston

Also, the fact that St. Vincent went to Genoa to try to help plague victims, ${ }^{24}$ connects his personage with St. Lazarus, depicted in this church. The saint depicted on the western side of this niche is a Franciscan monk, young, beardless with tonsured short brown hair. Like St. Vincent, he is not frontally depicted, but he is slightly turned to the little standing figure of Christ which he holds in his left arm. The depiction of Christ in the arm as well as the Franciscan clothes very clearly indicate the personage of St. Anthony of Padua. ${ }^{25}$ (fig. 4)

\footnotetext{
22 Z. JANEKOVIĆ RÖMER, Moć riječi: propovjednici u srednjovjekovnom Dubrovniku. in: Humanitas et litterae. Zbornik u čast Franje Šanjeka, LOVORKA ČORALIĆ, SLAVKO SLISKOVIĆ (ed.), Zagreb, 2009, p. 113.-125.

${ }^{23}$ The right side of this frescoe is severely damaged, but it seems he holds a book in his left arm. In the right hand he holds a red, longer object which is hard to recognize and could be flame. About the iconography of St. Vincent see: R. E. GUILEY, op. cit., p.343., Leksikon ikonografije ...., op. cit. p.618., http://www.newadvent.org/ cathen/15437a. htm, Downloaded: November 2013.

${ }^{24}$ Ibidem

${ }^{25}$ R. E. GUILEY, op. cit., p.29.- 31., Leksikon ikonografije ...., op. cit., p. 135., http://www.newadvent.org/ cathen/01556a. htm, Downloaded: November 2013.
} 


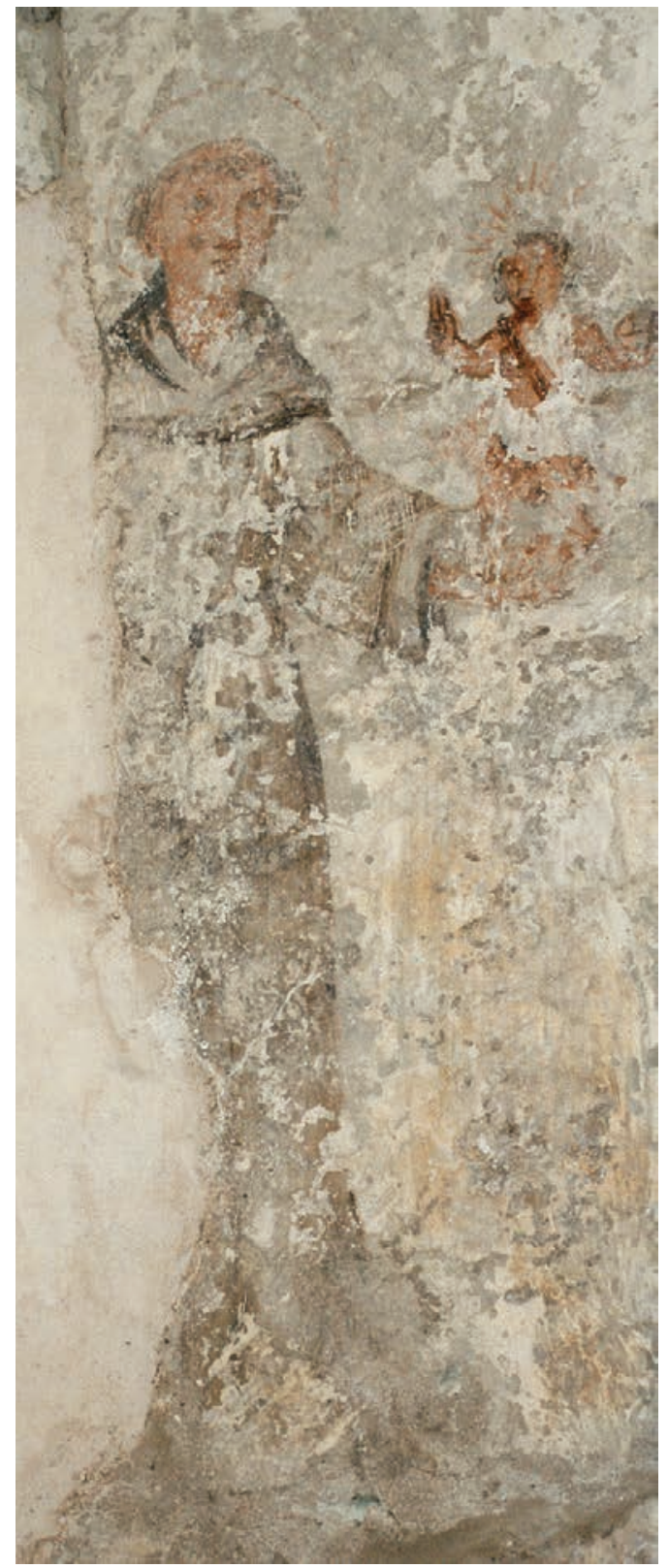

Fig. 4. St. Anthony of Padua, the southern wall, Gospa od Lužina Church in Ston

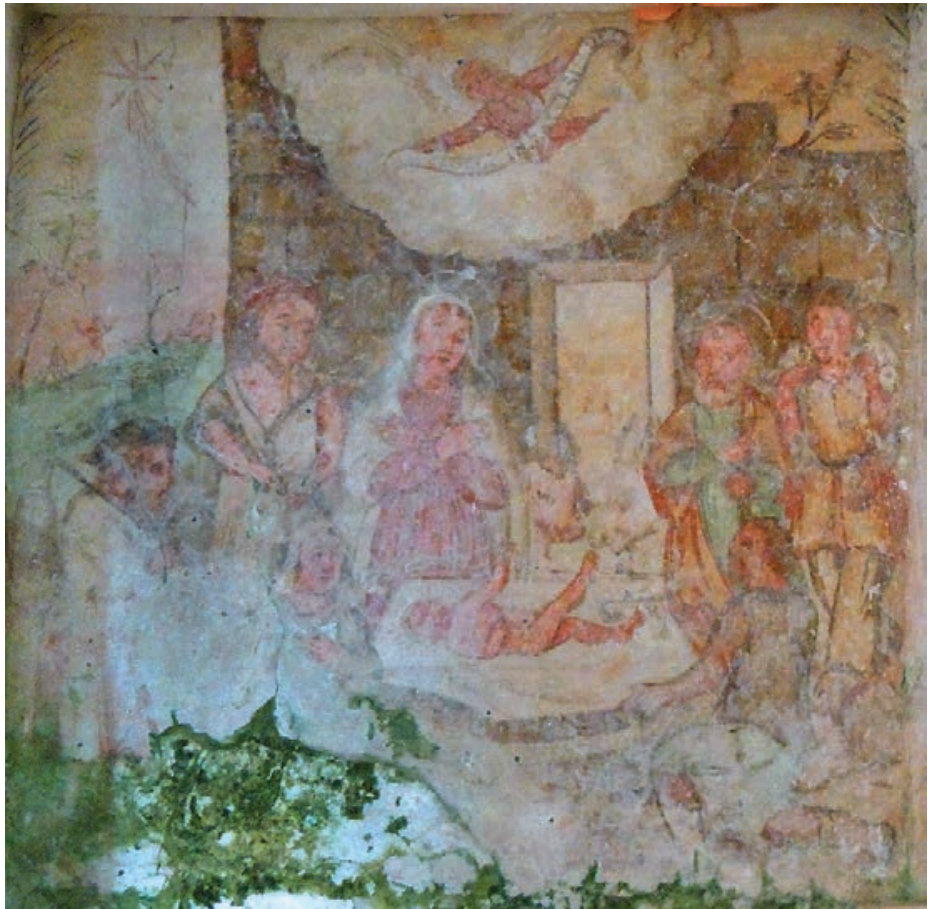

Fig. 5. Nativity, the northern wall, Gospa od Lužina Church in Ston

The remaining parts of the wall paintings in the Gospa od Lužina Church show mainly individually depicted figures, but there were also figural compositions on the walls of this church, as deduced from the remains of frescoes in the apsidal semi-dome and proved by relatively well preserved Nativity in the blind niche on the north wall. (fig. 5) This composition is compiled of many different iconographic elements. The Child is in the middle of the scene lying in the small, white bed while Mary and Joseph with cow and donkey are standing behind him. They are surrounded by several figures, probably shepherds. One angel in a white cloud is flying above the Child. Behind the central figures there is one stone wall, and on it's both sides a landscape is signed just by simply shaped trees. Two naked figures are dancing and lying on the ground in the distance and a big red shooting star is above them.

Despite the small quantity of preserved frescoes that makes impossible to know all what was depicted in this church, the idea of the basic nature of the iconography can be acquired. There are two main points. This iconography reveals an adherence to the old tradition of Christian art that is recognized in the program presented in the altar apse and on the eastern wall. At the same time, frescoes on the lateral walls confirm actuality of the iconography, its affiliation to the Catholic Church and familiarity with contemporary movements in it.

The western affiliation of this painting is also seen in its formal features, marked by attempts to achieve the realistic depiction. Despite their poor condition, it is obvious that connection with the Byzantine tradition disappeared. It is obvious in each element of the style.

The basic element of this painting is drawing. Each form is designated by contour and articulated by inner lines. There are some hard, stiff and tough lines, but soft, mainly curved and vivid lines, never black, which move freely on the surface, changing direction and strength are dominant. Such, 
almost plastic lines testify the effort of achieving volume that is enhanced by using different light values of colours which results with forms of strong volume. Sometimes, the volume is obtained or increased by perspective shortenings. The same role is given to more natural posture and body position, which completely abandoned frontality of traditional medieval painting.

It is impossible to get complete insight into the formal features. Little can be said about the use of light values, but some parts of the painting reveal that grading of light values associated with wide, free painterly strokes result in significant volume. The chromatic colour qualities cannot be analyzed, but it is clear, even in the existing conditions, that colouring does not follow the Byzantine tradition. There are neither usual coloristic assemblies of Byzantine painting nor gorgeous wide range of tones or coloristic warmth and softness. The colours are dry and according to what is left, it seems that simple colour assemblies were used. A cold light pink, used for skin-tones, is dominant. Also, one light green tone is frequent, so these two colours make the basic chromatic balance of this painting. The choice of colours and their coldness suggest certain Gothic impact on this painting.

The treatment of three dimensional space rendering reveals similar correlation with western art. It is not flat, two dimensional painting. Indications of space depth are regular as we can observe in the attitudes and turns of individually depicted saints as well as in the perspective shortenings. Such space treatment witnesses the commitment to realistic presentation that is confirmed by many other details such as the animals in the Nativity, the physiognomies of shepherds, even facial features of individually depicted saints. Realistic intentions are linked with the desire to show earthly, material beauty. These qualities resulted in humanized painterly expression that clearly closes the medieval eras and announces the arrival of the new one.

The stylistic features of this wall painting are useful as a guideline to its dating. Many elements that prove realism and interest for material beauty and some formulas taken from the Italian Quattrocento ${ }^{26}$ prove modernity of this painting and decisively abandonment of tradition. Tradition means not just Byzantine experience but the Gothic ones, too.

Unlike previous reviews on this painting, ${ }^{27}$ my opinion is that all the frescoes in the Gospa od Lužina Church were created at the same time. There are no significant stylistic and formal differences between them. Unfortunately, their poor condition prevents us to compare each visual element, but what is left indicates a high degree of correspondence. The same is confirmed by existing similarities in the physiognomies of the persons. It must be said that there are some differences, too. They are visible between proportions of corpulent figures in the apse and thinner, elegant ones beyond it. In my opinion, those differences are the result of unequal treatment of certain wall surfaces depending on their function in the sacral space as well as their size and shape. Proportions of the figures were determined by proportion of the surface which bears the depiction. This could indicate a painter who was not experienced in wall painting, confused with wide wall surface which had to be divided into smaller areas as it was the case with the wide apsidal wall.

Finally, when was the church painted? And, who could be the painter that did it?

In my opinion, this church was painted in the last two decades of the $15^{\text {th }}$ century. The depiction of St. Vincent Ferrer who died in 1419 and was canonized in 1455 sets these frescoes into the second half of the century. ${ }^{28}$ The individual depiction of St. Lazarus is useful, too. It undoubtedly denotes the protection against plague and had to be chosen after one of the plague outbreaks which were quite

\footnotetext{
${ }^{26}$ The background with ruins and deep idilic space behind it in which a few small, very distanced figures in the Nativity composition are the most important such elements.

${ }^{27} \mathrm{~N}$. Nađ dated the paining on the eastern wall and in the apse in the beginning of the $16^{\text {th }}$ century and the Nativity in the late $18^{\text {th }}$ century. V. B. Lupis mentioned a renessaince layer, below which he recognized older frescoes without dating them at all. He dated the Nativity into $17^{\text {th }}$ century as well as the dominicans and franciscan figures on the lateral walls. See: N. NAĐ, op. cit., p. 249., 250.; V. B. LUPIS, op. cit., p. 113., 114.

${ }^{28}$ R. E. GUILEY, op. cit., p.344., http://www.newadvent.org/cathen/15437a.htm, Downloaded: November 2013.
} 
common during the $15^{\text {th }}$ century. ${ }^{29}$ Comparing the years of plague outbreaks in Dubrovnik with the year of the canonization of St. Vincent Ferrer as well as the style and formal features of this painting leads to the conclusion that it could be executed not earlier than 1469 and more probably after 1483.

Such dating of the frescoes in the Gospa od Lužina Church is completely appropriate regarding the situation in the artistic life of that area. There are some documents which specify the activities of certain painters from Dubrovnik and Kotor in Ston during the $15^{\text {th }}$ century, ${ }^{30}$ including one that says that a big polyptich for the Gospa od Lužina church was completed in 1477 by Pavle Bazilj. ${ }^{31}$

It is very difficult to give a proposal for the attribution of these frescoes. In my opinion, the frescoes in the Gospa od Lužina church are the work of a local master who had already strongly abandoned the medieval tradition. These frescoes are different from chronologically close paintings in the area of Boka Kotorska where one can find traditional painting with a little influence of western styles ${ }^{32}$ or wall painting with the predominance of Gothic expression..$^{33}$ If the frescoes in the Gospa od Lužina Church and St. Michael church in Kotor were not so severely damaged it would be possible, perhaps, to establish some similarities between them as it is indicated by some fragments.

The frescoes in St. Michael church in Kotor were attributed to Lovro Dobričevićs ${ }^{4}$ attribution that is still questionned. ${ }^{35}$ That undoubtedly leads to the conclusion that the painting in the Gospa od Lužina Church should be placed in a circle of Lovro Dobričević followers, since they both chronologically and stylistically represent "the next generation" of art in the areas of southern Dalmatia. It would be wonderful to find enough elements to attribute this painting to Pavle Bazilj who was Dobričević's assistant and the author of the polyptich made for this church in 1477. Unfortunately, none of his works survived, so we cannot know what his painting was like and whether he was able to adopt a contemporary style of Italian art whose influence is obvious in this painting.

Although older researchers expressed the opinion about painting in Dubrovnik during the entire $15^{\text {th }}$ century as a quite conservative art, faithful to the traditions of Venetian Gothic without an open acceptance of any news from contemporary Italian art, ${ }^{36}$ the younger researchers like Ivana Prijatelj Pavičić think the opposite. She thinks that it is very possible that renaissance ideas could reach Dubrovnik between the 30-s and 50-s of the $15^{\text {th }}$ century. ${ }^{37}$ If this is correct, and it seems so, Pavle Bazilj or some other painter could be informed about the contemporary ideas in the Italian art of the second half of the $15^{\text {th }}$ century.

There are many questions about these frescoes without answers. It is to hope that there will be some new discoveries of the paintings, as well as new documents that will enable the defining of the frescoes in the Gospa od Lužina Church more precisely, and to get more complete knowledge of our old painting.

\footnotetext{
${ }^{29}$ B. STULLI, Povijest Dubrovačke republike, Dubrovnik - Zagreb, 1989., p.58.

${ }^{30}$ V. J. ĐURIĆ, Dubrovačka slikarska škola, Beograd, 1963., p.44., 54, 87.

${ }^{31}$ Ibid, p.85., V. B. Lupis, op. cit., p.112, I. PRIJATELJ PAVIČIĆ, U potrazi za izgubljenim slikarstvom, O majstoru Lovru iz Kotora i slikarstvu na prostoru od Dubrovnika do Kotora tijekom druge polovice XV. stoljeća, Dubrovnik, 2013., p.308.

${ }^{32}$ Such frescoes are in the church of St. Bazil in Stoliv.

${ }^{33}$ Such frescoes can be seen in the churches of St. Michael and St. Ane in Kotor.

${ }^{34}$ V. J. ĐURIĆ, U senci firentinske unije: Crkva Sv. Gospođe u Mržepu (Boka Kotorska) in: Zbornik radova Vizantološkog instituta, knj. XXXV, Beograd, 1996., p.40.

${ }^{35}$ R. VUJIČIĆ, Studije iz crnogorske istorije umjetnosti, Cetinje 1999., p.112., Ibidem, Srednjovjekovna arhitektura i slikarstvo Crne Gore, Podgorica 2007., p. 257-260.; Ibidem, Zidno slikarstvo, Catalogue of an exhibition, Zagovori svetom Tripunu, Blago kotorske biskupije at Klovićevi dvori, Zagreb 2009/2010., p. 79.-81.

${ }^{36}$ V. J. ĐURIĆ, (1963.), p.44.-87., S. RADOJČIĆ, O slikarstvu u Boki Kotorskoj in Spomenik CIII, Beograd, 1953, 58.

${ }^{37}$ I. PRIJATELJ PAVIČIĆ, op. cit., p. 84.-87.
} 


\section{FRESKE U CRKVI GOSPE OD LUŽINA U STONU}

Crkva Gospe od Lužina smještena je na blagom uzvišenju južno od Stona. Crkva je već duže vrijeme poznata u stručnoj javnosti, ali je tek zadnjim restauratorskim istraživanjima preciznije datirana u odmaklo 13. stoljeće. Tada su definirane i pojedine faze arhitektonskih preinaka na građevini te otkrivene do tada potpuno nepoznate zidne slike. Te su freske vrlo loše očuvane, ali se ipak može iščitati njihov sadržaj i u određenoj mjeri definirati formalno-stilska obilježja.

Najveća očuvana oslikana površina preostala je na zidu oltarske apside, gdje je u središnjem registru prikazano šest stojećih figura u arkadama. Središnja dva sveca nisu prikazana strogo hijeratski, frontalno, nego u izvijenom položaju kako pridržavaju velike razmotane rotuluse. Takvi frizovi figura na zidovima apsida, koji s vremenom počinju prikazivati doktore crkve, nisu neuobičajeni i predstavljaju redoviti program oslikavanja apsidalnih niša. Logično je zaključiti kako su u toj apsidi prikazani doktori crkve. Ne može se sa sigurnošću identificirati niti jedan od prikazanih svetaca, ali se, prema pročitanim riječima jednoga natpisa koje ukazuju na poeziju, ne na molitvu ili liturgiju, čini kako je jedan od njih sv. Ambrozije.

U polukaloti apside sačuvan je samo mali ulomak freske na kojemu se razaznaju tri mladolike, lijepe glave i dijelovi figura, čiji se točan broj, položaj, međusobni odnos i izgled ne mogu utvrditi. Oni gledaju prema središtu apside, što, zajedno s kerubinom koji leti prema njima ukazuje na kompoziciju koja je zauzimala čitavu površinu polukalote. Što je ta kompozicija prikazivala za sada je nemoguće utvrditi. Agnus Dei (?), s obzirom na rast popularnosti te teme u kasnosrednjovjekovnom slikarstvu, kao i odgovarajuće smještanje u oltarsku apsidu, mogao bi biti hipotetički prijedlog. Na tome mjestu nije bila prikazana Marija, budući da ostaci oslika, uz natpis koji prati luk apsidalnog otvora u vrhu istočnoga zida, svjedoče o njezinu prikazu iznad apside.

$\mathrm{Na}$ trijumfalnome luku prikazana su dvojica svetih biskupa - sv. Vlaho i sv. Lazar. Sv. Vlaho, zaštitnik Dubrovačke republike, slijedi uobičajenu ikonografiju, a u ruci drži maketu Stona prepoznatljiva oblika zidina. Sv. Lazar je lošije sačuvan i dosta neobično prikazan, individualno kao episkop uz kojega se vidi okvir groba u stijeni. Kult toga sveca bio je prilično razvijen na prostoru Dubrovačke republike zbog vjerovanja u njegovu zaštitu od kuge.

Dok se prikazima u apsidi i u vrhu istočnoga zida potvrđuje vanvremenski, opći karakter slikarstva, a ličnostima sv. Vlahe i sv. Lazara otkriva njihov regionalni karakter, u sadržaju fresaka na bočnim zidovima istočnog traveja pokazuje se njegova povezanost sa suvremenim temama koje se razvijaju u to vrijeme u okviru umjetnosti zapadne crkve. O tome jasno govore prikazi sv. Franje, sv. Dominika, sv. Antuna Padovanskog i Vinka Fererskoga. Oni su istaknuti franjevci i dominikanci, osnivači i pripadnici utjecajnih crkvenih redova koji su i na prostoru Dubrovnika u to vrijeme bili vrlo aktivni.

Osim pojedinačnih figura, u crkvi su bile naslikane i neke narativne kompozicije, kao što je Rođenje Kristovo u slijepoj niši na sjevernome zidu istočnoga traveja. Ta kompozicija ikonografskim pojedinostima ukazuje na povezanost sa suvremenim zbivanjima u talijanskoj umjetnosti.

Jednako kako se u ikonografiji prepoznaje zapadni karakter toga slikarstva, njegovo definitivno odvajanje od bizantskih tradicija se uočava i u stilu i formalnim svojstvima, što je najjasnije u snažnim nastojanjima stvaranja dojma prostorne dubine, snažnih volumena, te uvođenju rezultata opažanja pojavnoga svijeta u sliku.

Takva stilska svojstva, kao i ikonografske pojedinosti, zidne slike u crkvi Gospe od Lužina smještaju u posljednja desetljeća 15. st. Nepostojanje važnijih formalnih razlika između pojedinih dijelova tog oslika osporava ranije iznesene pretpostavke o više faza njihova nastanka.

Konačno, iako se ne može dati prijedlog atribucije tih fresaka, to se slikarstvo ipak može povezati s umjetničkom produkcijom dubrovačkog prostora. One su ostvarenje domaćeg majstora koji je napustio gotičke i bizantske umjetničke tradicije.

Otkriće fresaka u crkvi Gospe od Lužina u Stonu izuzetno je važno, jer iako ne daje mogućnosti njegove atribucije i precizne datacije, ono povećava svekolilki fundus našeg starog slikarstva i otvara 
pitanje karaktera i stupnja progresivnosti dubrovačkog slikarstva krajem 15. stoljeća u kontekstu njegove sposobnosti prihvaćanja postignuća talijanskog Quattrocenta.

Ključne riječi: Gospa od Lužina, freske, doktori crkve, Agnus Dei, sv. Franjo, sv. Dominik, Vinko Fererski sv. Ante Padovanski, Rođenje, Quattrocento 